\title{
Toll-like receptors in esophageal cancer
}

\author{
Joonas H. Kauppila ${ }^{1,2,3,4}$ * and Katri S. Selander ${ }^{5,6}$ \\ ${ }^{1}$ Department of Pathology, University of Oulu, Oulu, Finland \\ ${ }^{2}$ Department of Surgery, University of Oulu, Oulu, Finland \\ ${ }^{3}$ Medical Research Center Oulu, Oulu, Finland \\ ${ }^{4}$ Oulu University Hospital, Oulu, Finland \\ ${ }^{5}$ Department of Hematology-Oncology, University of Alabama at Birmingham, Birmingham, AL, USA \\ ${ }^{6}$ Department of Pathology, Lapland Central Hospital, Rovaniemi, Finland
}

\section{Edited by:}

Anton G. Kutikhin, Research Institute for Complex Issues of Cardiovascular Diseases under the Siberian Branch of the Russian Academy of Medical Sciences, Russia

\section{Reviewed by:}

Anton G. Kutikhin, Research Institute for Complex Issues of Cardiovascular Diseases under the Siberian Branch of the Russian Academy of Medical Sciences, Russia

Arseniy E. Yuzhalin, University of

Oxford, UK

\section{*Correspondence:}

Joonas H. Kauppila, Department of Pathology, University of Oulu, PO-Box 5000, 90014 Oulu, Finland

e-mail: joonas.kauppila@oulu.fi
Esophageal squamous cell carcinoma and esophageal adenocarcinoma are cancers of high mortality. EAC develops through Barrett's esophagus (BE) and columnar dysplasia, preceded by gastro-esophageal reflux disease. The risk of esophageal squamous cell carcinoma is increased by smoking and alcohol consumption. New treatment options for esophageal cancer are desperately needed. Toll-like receptors (TLRs) play a central role in mammalian immunity and cancer. TLRs are activated by microbial components, such as lipopolysaccharide, flagellin, DNA, and RNA, as well as endogenous ligands, including heat-shock proteins and endogenous DNA. This review summarizes the studies on TLRs in esophageal squamous cell carcinoma and EAC. It has been shown that TLRs 1-10 are expressed in the normal esophagus. In esophageal squamous cell carcinoma, TLRs3, 4, 7, and 9 have been studied, showing associations to aggressive disease properties. In BE and EAC, only TLRs4, 5, and 9 have been studied. In the review, we discuss the implications of TLRs in esophageal cancer.

Keywords:Toll-like receptors, microbiome, esophageal cancer, esophageal adenocarcinoma, esophageal squamous cell carcinoma

\section{INTRODUCTION}

Toll-like receptors (TLRs) are evolutionarily conserved receptors of the innate immune system (1). The 13 TLRs that have been identified so far recognize their unique pathogen-associated molecular patterns (PAMPs), such as bacterial lipopolysaccharide (LPS) (TLR4), DNA (TLR9), or flagellin (TLR5) $(1,2)$. TLR stimulation induces down-stream activation of various signaling molecules and this ultimately results in the innate immune response, which also activates the adaptive immune system (13). The aim of this review is to explore the role and function of TLRs in esophageal adenocarcinoma (EAC) and in squamous cell carcinoma.

\section{ESOPHAGEAL CANCER}

Esophageal cancer is the eighth most common cancer in the world with estimated 482,000 new cases worldwide in 2008. The incidence of esophageal cancer was 70/100,000 in 2008 in the world. The majority of esophageal cancers are esophageal squamous cell carcinomas (ESCC), but the incidence of EAC is rising rapidly $(4,5)$.

As with oral squamous cell cancer, tobacco and alcohol, low socioeconomic status, poor oral health, and betel nuts, as well as the autoimmune polyendocrinopathy-candidiasis-ectodermal dystrophy (APECED)-syndrome have been listed as risk factors for ESCC (6-10). With regard to pathologic anatomy, esophagus could be considered as an extension of the oral cavity, as it is lined by squamous epithelium and it encounters swallowed oral bacteria before they enter the stomach.
For EAC, the most important risk factor is Barrett's esophagus (BE), determined by columnar metaplastic cells, which replace the normal squamous epithelium after long-lasting gastro-esophageal reflux, or gastro-esophageal reflux disease (GERD). Patients with BE have a 30- to 125-fold risk for EAC compared to normal population $(11,12)$. A recent study, however, concluded that only $0.12 \%$ of patients with BE develop EAC (13). Other minor risk factors include obesity, smoking, hiatal hernia, and low socioeconomic status $(10,14-18)$. Furthermore, both types of esophageal cancers develop through dysplasia to cancer via genetic alterations $(19,20)$.

The 5-year survival rate for esophageal cancer varies between 10 and $16 \%(4)$. After esophageal resection, the 5-year survival rate was $20.6 \%$ in a meta-analysis of Western population (21). Furthermore, these cancers are often diagnosed late because at the time of the diagnosis, more than half of the patients have an inoperable disease (22).

The most important prognostic determinant for both esophageal cancers is the WHO TNM-classification (23). The histologically defined grade of differentiation is also a predictor of prognosis (24).

\section{TOLL-LIKE RECEPTORS IN NORMAL ESOPHAGUS}

Esophageal epithelial cells have been shown to express TLRs. The human esophageal epithelial cell-line TE-1 was shown to express TLRs2, 3, 4, and 7, with up-regulation of beta-defensin 2 as a response to stimulation with their cognate, synthetic ligands (25). In 2009, Lim and colleagues demonstrated the expression of TLRs $1-10$, but not TLR4 at the mRNA level in the normal human 
esophageal epithelial cell-line EPC-2. Furthermore, they demonstrated TLR1, 2, 3, and 5 mRNA expression in biopsies taken from esophageal mucosa. IL- 8 was up-regulated in the EPC- 2 cells by stimulation of the respective TLR-ligands. TLR3 stimulation was the most effective in inducing IL-8 expression synergistically with TLR2 and this effect was dependent on NF-kB activation (26).

TLR3 was later demonstrated also to mediate the induction of IL-8 mRNA via NF-kB by necrotic cell supernatants in the EPC-2 cells (27). TLR2 and TLR3 protein expression was demonstrated in esophageal epithelial cells, but not in cultured primary esophageal epithelial cells (28). The expression of TLR3, 4, 5, 7, and 9 proteins in normal esophagus has been characterized using immunohistochemistry in clinical samples (29-31). These studies have demonstrated that TLRs $1-10$ are expressed in normal esophagus.

\section{TOLL-LIKE RECEPTORS AND ESOPHAGEAL SOUAMOUS CELL CARCINOMA}

Esophageal squamous cell carcinoma develops to squamous epithelium via dysplasia. A variety of TLRs, including TLR3, 4, 7 , and 9, have been shown to be overexpressed in esophageal squamous cell carcinoma, when compared to normal esophagus (30, 31). We demonstrated an increased TLR9 expression in esophageal squamous dysplasia and in squamous cell carcinoma, suggesting a possible role for TLR9 in esophageal carcinogenesis (31).

High TLR3, 4, and 9 expression in esophageal squamous cell carcinoma cells have been associated with lymph node metastasis and TLR7 and 9 expression to worse histological grade (30, 31). TLR9 expression in the fibroblastoid cells of the tumor was, however, associated with decreased invasion depth and a smaller prevalence of lymph node metastasis at the time of diagnosis (30). TLR4 stimulation by LPS has been shown to increase migration and adhesive properties of esophageal squamous cell carcinoma cells via p38 and selectin (32). No studies thus far have evaluated the anti-cancer efficacy of TLR-agonists or inhibitors in the treatment of ESCC.

\section{TOLL-LIKE RECEPTORS, BARRETT'S ESOPHAGUS, AND ESOPHAGEAL ADENOCARCINOMA}

Esophageal adenocarcinoma is developed through the metaplasiadysplasia-carcinoma sequence. Normal or inflamed esophageal epithelium is believed to transform to BE or columnar metaplasia through continuous exposure to acidic gastric contents, but also transformation of esophageal microbiome occurs during these changes $(33,34)$.

It was shown in $\mathrm{BE}$ and in normal human esophageal cell lines, that stimulation of TLR 4 with LPS resulted in NF- $\kappa B$ activation and an increase of IL- 8 secretion, this response was more significant in BE. Ex vivo culture demonstrated increased cyclooxygenase-2 (COX-2) activation by LPS stimulation of TLR4 in BE (35). TLR5 was recently analyzed in the metaplasia-dysplasiaadenocarcinoma sequence, with high expression potentially differentiating between BE and columnar dysplasia (29).

The increased expression of TLR5 and 9 has been shown in EAC. TLR5 expression had no associations to clinico-pathological variables or prognosis, but TLR9 expression was associated with metastasis, poor grade of differentiation and poor prognosis in EAC $(29,36)$. Stimulation of EAC cells with CpG-oligonucleotides that either have the physiological phosphodiester DNA-backbone or the nuclease-resistant phosphothioate backbone, induced cellular invasion and matrix metalloproteinase- 9 and -13 mRNA expression (37).

At the current moment, there are no published clinical studies on TLRs in EAC.

\section{TOLL-LIKE RECEPTOR GENETICS AND ESOPHAGEAL CANCER}

Genetic studies have been performed on Toll-like receptor polymorphisms in esophageal cancer. Unlike in gastric cancer, polymorphisms in TLR4 $+896 A>G$ and TLR9-1237T/C genes were not associated to esophageal cancer risk $(38,39)$. However, genetic up-regulation of CD14, a co-receptor of TLR4, was observed in families with history of esophageal cancer (40).

\section{DISCUSSION}

The treatment of esophageal cancer is overshadowed by its poor prognosis. New options for early diagnosis and treatment are desperately needed. The esophageal epithelium encounters bacteria from oral cavity and in the case of reflux disease, also from the stomach and possibly also from the duodenum. TLRs act by recognizing bacteria-derived molecular patterns which results in a pro-inflammatory reaction in the epithelium.

The role of TLRs in esophageal cancer has been studied sparsely. However, there is evidence that the function of TLRs is procarcinogenic and pro-inflammatory as the overexpression of many of the TLRs have been linked with esophageal cancer and with poor prognosis. Inflammation is a known important factor in the pathogenesis of various cancers. It was demonstrated by Yang et al. that the microbiome of distal esophagus frequently undergoes changes during esophagitis and BE. During these processes, the microbiome is switched from aerobic to gram-negative anaerobic bacteria $(33,34)$. This finding together with abnormal TLR expression, particularly those of TLRs4, 5, and 9, in esophageal cancer supports the hypothesis of bacteria contributing to the carcinogenesis of esophageal cancer. These findings further suggest that TLRs may be important mediators for bacteria in oncogenesis $(37,40,41)$.

In addition to microbes, TLRs can also detect molecular patterns that are derived from the host itself. TLRs3, 4, and 9 are known to be activated by endogenous ligands from dead or damaged host cells $(42,43)$. The combination of cellular damage by alcohol, tobacco, and acidic contents of the stomach results in the loss of epithelial wall integrity, through epithelial cell death and by disruption of the cell-to-cell contacts. Especially TLR3 and TLR9 (but also other TLRs) can recognize particles from dead cells (43). This can result in an inflammatory wound reaction through the activation of interleukins, NF-kB, and matrix metalloproteinases. This wound reaction could facilitate the passage of bacteria through epithelium and result in the loss of hostmicrobiome homeostasis, further leading to abnormal activation of for example TLR2, 4, 5, and 9 by bacterial components. Inflammation and wound reaction then could produce a vicious cycle of cellular damage, which might be a major player in esophageal metaplasia and carcinogenesis. This role of bacteria and TLR4 in genesis of BE has been discussed earlier by Yang et al. (33). Cell-to-cell junctions become dysfunctional in exogenous damage to the epithelium as discussed earlier. Thus, a similar effect can also 


\section{Normal epithelium}

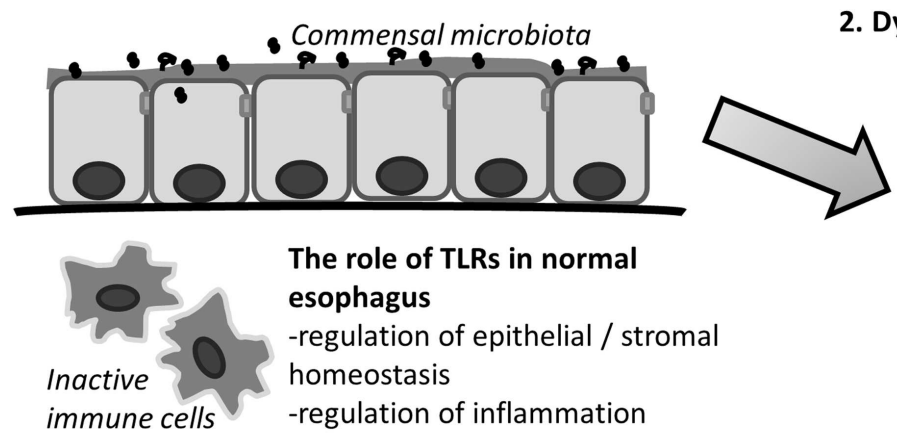

immune cells -regulation of inflammation

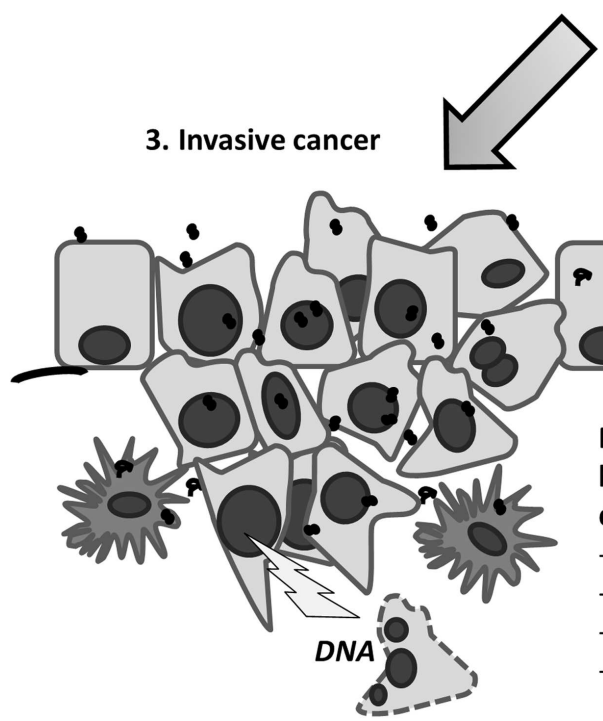

2. Dysplasia / carcinoma in situ

Alcohol

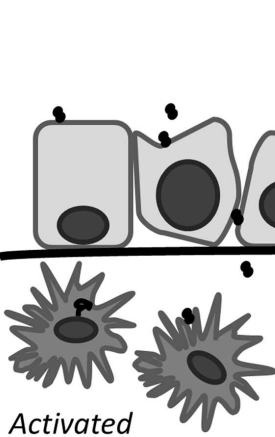

Immune cells
Tobacco

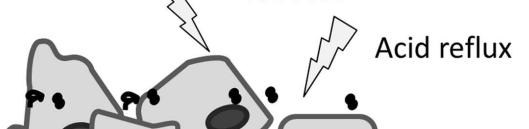


9. Rautemaa R, Hietanen J, Niissalo S, Pirinen S, Perheentupa J. Oral and oesophageal squamous cell carcinoma - a complication or component of autoimmune polyendocrinopathy-candidiasis-ectodermal dystrophy (APECED, APS-I). Oral Oncol (2007) 43(6):607-13. doi:10.1016/j.oraloncology. 2006.07.005

10. Kamangar F, Chow WH, Abnet CC, Dawsey SM. Environmental causes of esophageal cancer. Gastroenterol Clin North Am (2009) 38(1):27-57,vii. doi:10. 1016/j.gtc.2009.01.004

11. Fitzgerald RC. Molecular basis of Barrett's oesophagus and oesophageal adenocarcinoma. Gut (2006) 55(12):1810-20. doi:10.1136/gut.2005.089144

12. Sikkema M, de Jonge PJ, Steyerberg EW, Kuipers EJ. Risk of esophageal adenocarcinoma and mortality in patients with Barrett's esophagus: a systematic review and meta-analysis. Clin Gastroenterol Hepatol (2010) 8(3):235-44;quiz32. doi: 10.1016/j.cgh.2009.10.010

13. Hvid-Jensen F, Pedersen L, Drewes AM, Sorensen HT, Funch-Jensen P. Incidence of adenocarcinoma among patients with Barrett's esophagus. N Engl J Med (2011) 365(15):1375-83. doi:10.1056/NEJMoa1103042

14. Jansson C, Johansson AL, Nyren O, Lagergren J. Socioeconomic factors and risk of esophageal adenocarcinoma: a nationwide Swedish case-control study. Cancer Epidemiol Biomarkers Prev (2005) 14(7):1754-61. doi:10.1158/1055-9965. EPI-05-0140

15. Corley DA, Kubo A, Levin TR, Block G, Habel L, Zhao W, et al. Abdominal obesity and body mass index as risk factors for Barrett's esophagus. Gastroenterology (2007) 133(1):34-41; quiz 311. doi:10.1053/j.gastro.2007.04.046

16. Holmes RS, Vaughan TL. Epidemiology and pathogenesis of esophageal cancer. Semin Radiat Oncol (2007) 17(1):2-9. doi:10.1016/j.semradonc.2006.09.003

17. Abnet CC, Freedman ND, Hollenbeck AR, Fraumeni JF Jr, Leitzmann M, Schatzkin A. A prospective study of BMI and risk of oesophageal and gastric adenocarcinoma. Eur J Cancer (2008) 44(3):465-71. doi:10.1016/j.ejca. 2007.12.009

18. Corley DA, Kubo A, Zhao W. Abdominal obesity and the risk of esophageal and gastric cardia carcinomas. Cancer Epidemiol Biomarkers Prev (2008) 17(2):352-8. doi:10.1158/1055-9965.EPI-07-0748

19. Koppert LB, Wijnhoven BP, van Dekken H, Tilanus HW, Dinjens WN. The molecular biology of esophageal adenocarcinoma. J Surg Oncol (2005) 92(3):169-90. doi:10.1002/jso.20359

20. Cai YC, So CK, Nie AY, Song Y, Yang GY, Wang LD, et al. Characterization of genetic alteration patterns in human esophageal squamous cell carcinoma using selected microsatellite markers spanning multiple loci. Int J Oncol (2007) 30(5):1059-67. doi:10.3892/ijo.30.5.1059

21. Hulscher JB, Tijssen JG, Obertop H, van Lanschot JJ. Transthoracic versus transhiatal resection for carcinoma of the esophagus: a meta-analysis. Ann Thorac Surg (2001) 72(1):306-13. doi:10.1016/S0003-4975(00)02570-4

22. Shahbaz Sarwar CM, Luketich JD, Landreneau RJ, Abbas G. Esophageal cancer: an update. Int J Surg (2010) 8(6):417-22. doi:10.1016/j.ijsu.2010.06.011

23. Sobin LH, Gospodarowicz MK, Wittekind C, editors. International union against cancer. TNM Classification of Malignant Tumours. 7th ed. Chichester: WileyBlackwell (2010). 309 p.

24. Liu J, Xie X, Zhou C, Peng S, Rao D, Fu J. Which factors are associated with actual 5-year survival of oesophageal squamous cell carcinoma? Eur J Cardiothorac Surg (2012) 41(3):e7-11. doi:10.1093/ejcts/ezr240

25. Uehara A, Fujimoto Y, Fukase K, Takada H. Various human epithelial cells express functional Toll-like receptors, NOD1 and NOD2 to produce anti-microbial peptides, but not proinflammatory cytokines. Mol Immunol (2007) 44(12):3100-11. doi:10.1016/j.molimm.2007.02.007

26. Lim DM, Narasimhan S, Michaylira CZ, Wang ML. TLR3-mediated NF$\{$ kappa\}B signaling in human esophageal epithelial cells. Am J Physiol Gastrointest Liver Physiol (2009) 297(6):G1172-80. doi:10.1152/ajpgi.00065.2009

27. Lim DM, Wang ML. Toll-like receptor 3 signaling enables human esophageal epithelial cells to sense endogenous danger signals released by necrotic cells. Am J Physiol Gastrointest Liver Physiol (2011) 301(1):G91-9. doi:10.1152/ajpgi. 00471.2010

28. Mulder DJ, Lobo D, Mak N, Justinich CJ. Expression of toll-like receptors 2 and 3 on esophageal epithelial cell lines and on eosinophils during esophagitis. Dig Dis Sci (2012) 57(3):630-42. doi:10.1007/s10620-011-1907-4

29. Helminen O, Huhta H, Takala H, Lehenkari PP, Saarnio J, Kauppila JH, et al. Increased Toll-like receptor 5 expression indicates esophageal columnar dysplasia. Virchows Arch (2014) 464(1):11-8. doi:10.1007/s00428-013-1505-2
30. Sheyhidin I, Nabi G, Hasim A, Zhang RP, Ainiwaer J, Ma H, et al. Overexpression of TLR3, TLR4, TLR7 and TLR9 in esophageal squamous cell carcinoma. World J Gastroenterol (2011) 17(32):3745-51. doi:10.3748/wjg.v17.i32.3745

31. Takala H, Kauppila JH, Soini Y, Selander KS, Vuopala KS, Lehenkari PP, et al. Toll-like receptor 9 is a novel biomarker for esophageal squamous cell dysplasia and squamous cell carcinoma progression. J Innate Immun (2011) 3(6):631-8. doi:10.1159/000329115

32. Rousseau MC, Hsu RY, Spicer JD, McDonald B, Chan CH, Perera RM, et al. Lipopolysaccharide-induced toll-like receptor 4 signaling enhances the migratory ability of human esophageal cancer cells in a selectin-dependent manner. Surgery (2013) 154(1):69-77. doi:10.1016/j.surg.2013.03.006

33. Yang L, Francois F, Pei Z. Molecular pathways: pathogenesis and clinical implications of microbiome alteration in esophagitis and Barrett esophagus. Clin Cancer Res (2012) 18(8):2138-44. doi:10.1158/1078-0432.CCR-11-0934

34. Yang L, Lu X, Nossa CW, Francois F, Peek RM, Pei Z. Inflammation and intestinal metaplasia of the distal esophagus are associated with alterations in the microbiome. Gastroenterology (2009) 137(2):588-97. doi:10.1053/j.gastro.2009. 04.046

35. Verbeek RE, Siersema PD, Ten Kate FJ, Fluiter K, Souza RF, Vleggaar FP, et al. Toll-like receptor 4 activation in Barrett's esophagus results in a strong increase in COX-2 expression. J Gastroenterol (2013). doi:10.1007/s00535-013-0862-6

36. Kauppila JH, Takala H, Selander KS, Lehenkari PP, Saarnio J, Karttunen TJ. Increased Toll-like receptor 9 expression indicates adverse prognosis in oesophageal adenocarcinoma. Histopathology (2011) 59(4):643-9. doi:10.1111/ j.1365-2559.2011.03991.x

37. Kauppila JH, Karttunen TJ, Saarnio J, Nyberg P, Salo T, Graves DE, et al. Short DNA sequences and bacterial DNA induce esophageal, gastric, and colorectal cancer cell invasion. APMIS (2013) 121(6):511-22. doi:10.1111/apm.12016

38. Hold GL, Rabkin CS, Gammon MD, Berry SH, Smith MG, Lissowska J, et al. CD14-159C/T and TLR9-1237T/C polymorphisms are not associated with gastric cancer risk in Caucasian populations. Eur J Cancer Prev (2009) 18(2):117-9. doi:10.1097/CEJ.0b013e3283101292

39. Hold GL, Rabkin CS, Chow WH, Smith MG, Gammon MD, Risch HA, et al. A functional polymorphism of toll-like receptor 4 gene increases risk of gastric carcinoma and its precursors. Gastroenterology (2007) 132(3):905-12. doi:10.1053/j.gastro.2006.12.026

40. Chattopadhyay I, Phukan R, Singh A, Vasudevan M, Purkayastha J, Hewitt S, et al. Molecular profiling to identify molecular mechanism in esophageal cancer with familial clustering. Oncol Rep (2009) 21(5):1135-46. doi:10.3892/or_00000333

41. Kauppila JH, Mattila AE, Karttunen TJ, Salo T. Toll-like receptor 5 and the emerging role of bacteria in carcinogenesis. Oncoimmunology (2013) 2(4):e23620. doi:10.4161/onci.23620

42. Yu L, Wang L, Chen S. Endogenous toll-like receptor ligands and their biological significance. J Cell Mol Med (2010) 14(11):2592-603. doi:10.1111/j.1582-4934. 2010.01127.x

43. Tuomela J, Sandholm J, Kaakinen M, Patel A, Kauppila JH, Ilvesaro J, et al. DNA from dead cancer cells induces TLR9-mediated invasion and inflammation in living cancer cells. Breast Cancer Res Treat (2013) 142(3):477-87. doi:10.1007/s10549-013-2762-0

44. Ding L, Lu Z, Lu Q, Chen YH. The claudin family of proteins in human malignancy: a clinical perspective. Cancer Manag Res (2013) 5:367-75. doi:10.2147/ CMAR.S38294

Conflict of Interest Statement: The authors declare that the research was conducted in the absence of any commercial or financial relationships that could be construed as a potential conflict of interest.

Received: 10 April 2014; paper pending published: 19 April 2014; accepted: 23 April 2014; published online: 07 May 2014.

Citation: Kauppila JH and Selander KS (2014) Toll-like receptors in esophageal cancer. Front. Immunol. 5:200. doi: 10.3389/fimmu.2014.00200

This article was submitted to Tumor Immunity, a section of the journal Frontiers in Immunology.

Copyright (C) 2014 Kauppila and Selander. This is an open-access article distributed under the terms of the Creative Commons Attribution License (CC BY). The use, distribution or reproduction in other forums is permitted, provided the original author(s) or licensor are credited and that the original publication in this journal is cited, in accordance with accepted academic practice. No use, distribution or reproduction is permitted which does not comply with these terms. 